\title{
Effects of Electroporation on Anticancer Activity of 5-FU and Newly Synthesized zinc(II) Complex in Chemotherapy-resistance Human Brain Tumor Cells
}

\section{Mehmet Eşref Alkış ( $\nabla$ me.alkis@alparslan.edu.tr)}

Muş Alparslan Üniversitesi: Mus Alparslan Universitesi https://orcid.org/0000-0002-3321-2873

Nevin Turan

Muş Alparslan Üniversitesi: Mus Alparslan Universitesi

Yusuf Alan

Muş Alparslan Üniversitesi: Mus Alparslan Universitesi

Sevgi Irtegun Kandemir

Dicle University: Dicle Universitesi

\section{Kenan Buldurun}

Muş Alparslan Üniversitesi: Mus Alparslan Universitesi

\section{Research Article}

Keywords: Zn(II) complex, 5-Fluorouracil, Electrochemotherapy, Anticancer activity, Spectral techniques

Posted Date: June 29th, 2021

DOI: https://doi.org/10.21203/rs.3.rs-649109/v1

License: (c) (1) This work is licensed under a Creative Commons Attribution 4.0 International License. Read Full License

Version of Record: A version of this preprint was published at Medical Oncology on September 22nd, 2021. See the published version at https://doi.org/10.1007/s12032-021-01579-7. 


\section{Abstract}

$\mathrm{Zn}$ (II) complex of Schiff base derived from the condensation of 4-aminopyrimidine-2(1H)-one with salicylaldehyde was prepared and characterized by various physico-chemical and spectral methods for structure determination. The cytotoxic activity of the $\mathrm{Zn}$ (II) complex was investigated in comparison with 5-fluorouracil (5-FU) against two different human brain tumor cell lines (T98G and U118), while primer human dermal fibroblast cells (HDF) was used as control for biocompatibility. Then, the effectiveness of electroporation (EP) on cytotoxic activities of these compounds has been examined. The cytotoxicities of the 5-FU and new Zn(II) complex, alone or in combination with electroporation, were determined by MTT assay. The Zn(II) complex showed good cytotoxicity against T98G and U118 brain tumor cell lines with $I_{50}=282.47$ and $297.91 \mu \mathrm{M}$ respectively, while it was safe on HDF healthy cells with $\mathrm{IC}_{50}=826.72 \mu \mathrm{M}$. The 5-FU exhibited less cytotoxicity compared to the $\mathrm{Zn}(\mathrm{II})$ complex against T98G $\left(\mathrm{IC}_{50}=382.35 \mu \mathrm{M}\right)$ and $\mathrm{U} 118\left(\mathrm{IC}_{50}=396.56 \mu \mathrm{M}\right)$ tumor cell lines. The combined application of $\mathrm{Zn}(\mathrm{II})+\mathrm{EP}$ decreased the $\mathrm{IC}_{50}$ value by 5.96 -fold in T98G cells and 4.76 -fold in U118 cells. EP showed a similar effect in its combined application with $5-\mathrm{FU}$, resulting in a decrease of the $\mathrm{IC}_{50}$ value of 4.22 -fold in the T98G cells and 3.84-fold in the U118 cells. In a conclusion, the Zn(II) complex exhibited an anticancer potential against both brain tumor cell lines (T98G and U118) and EP greatly increased the cytotoxicity of Zn(II) complex and 5-FU on these chemotherapy-resistant cells.

\section{Highlights}

- Novel Zn(II) complex were synthesized and characterized by various physico-chemical and spectral methods.

- The cytotoxic activity of the Zn(II) complex was investigated in comparison with 5-Fu against T98G, U118 and fibroblast (HDF) cell lines.

- Electroporation greatly enhanced the anticancer effect of Zn(II) complex and 5-Fu in brain chemotherapy-resistant cells.

- The application of the new $\mathrm{Zn}$ (II) complex alone or in combination with electroporation showed higher cytotoxicity than 5-Fu in the treatment of T98G and U118 brain tumor cell lines.

\section{Introduction}

Schiff bases are known as compounds containing the azomethine functionality (-HC=N-). Schiff bases are not only good a-donors but also very excellent $\pi$-acid ligands, as these could accept the electronic density into empty $\pi^{*}$-antibonding molecular orbitals of azomethine group from metal possessing low oxidation states. The Schiff bases, with the aid of the phenolic group at o-position, can operate as monobasic bidentate ligands in nature and form the basis of coordination chemistry with a range of metal ions. Schiff bases are considered to be a versatile pharmacophore for the drug design and development of numerous bioactive compounds. They serve a vital role in industrial, herbicidal, antibacterial, antifungal and anticancer applications, especially when complexed with transition metals 
[1-4]. It is well known that various Schiff base complexes of $\mathrm{Cu}(\mathrm{II}), \mathrm{Zn}(\mathrm{II})$, and $\mathrm{Ni}(\mathrm{II})$ are used as antiinflammatory, anti-bacterial, anti-diabetic, chemo-sensors, anti-cancer, antipyretic and anti-HIV $[5,6]$.

Cancer ranks the second among the causes of deaths worldwide and is still one of the major threats to public health across the world. Chemotherapy (CT) is an effective method in the treatment of cancer; however, when it is applied in a traditional way, it causes some serious side effects such as resistance to drugs and the lack of selectivity where the normal body cells are also affected by the anti-cancer drugs [7]. Glioblastoma is known to be the most common primary brain tumor and its incidence is on the rise globally. Surgical resection is used in combination with chemo- and radio-therapy as the standard treatment for patients with glioblastoma multiform (GBM); however, GBM has a poor prognosis and its median survival time does not exceed two years [8]. This can be explained by the fact that it tends to show an infiltrative growth pattern and resists the therapy, which leads to a high rate of recurrence and finally a therapeutic failure [9]. Therefore, scientists have focused on finding alternative methods of treatment and developing antitumor complexes targeting the tumor cells in a selected way with low toxicity and high efficacy.

Various synthesized chemical compounds are used in cancer treatment, and in the clinical practice, 5fluorouracil (5-FU) commonly used as a first-line anticancer drug [10]. 5-FU considerably decreases thymidine, and by doing so, prevents the RNA and DNA synthesis and shows its anti-cancer effect [11]. When the cancer cell is deficient in functional RNA and DNA, it cannot reproduce and make vital proteins, resulting in cell death. By this means, 5-FU slows/stops the cancer cell growth in various oncologic conditions. 5-FU is related to severe adverse effects in the clinical application [12]; therefore, it is important to find new anticancer agents that have no severe side effects on normal cells. Zinc is the second most plentiful trace element in the human body and an important micro-element that is essential for human physiology [13]. Moreover, zinc has a neuromodulator function in the brain as well as its other cellular functions [14]. Besides these functions, it has some beneficial therapeutic/preventive effects on cancer. Recent research has revealed that $\mathrm{Zn}$ (II) derivatives could be potentially used as an anticancer agent with low adverse effects and toxicity and different modes of action and cellular targets compared to the traditional metal-based drugs $[15,16]$.

The efficacy of a chemotherapeutic drug depends on its uptake into the tumor cell. In case a drug has a poor permeability, a higher dose is required for an effective cytotoxicity to the tumor cell, and this causes more adverse effects [17]. Electroporation (EP), a microbiology method where intense and short electric pulses are applied to make the cell membrane temporarily more permeable, is used to increase the drug entry into the chemo-resistant cancer cells [18]. Thanks to the permeability provided by EP, a lower dose of an anticancer drug applied for a shorter time can be enough for an effective therapy, which minimizes the adverse effects seen in chemotherapy. Electrochemotherapy (ECT) is a treatment method where the tumor nodules are treated by EP after the drug is administered systemically or locally. ECT is effective in cutaneous/subcutaneous melanomas and can be used in various malignant lesions [19]. Preclinical studies have shown that ECT can be effective and tolerable in the soft tissues like brain [20]. 
Herein, a new zinc(II) complex, $\left[\mathrm{ZnL}_{2}\right] \mathrm{Cl}_{2} \mathrm{H}_{2} \mathrm{O}$, where $\mathrm{L}$ is the deprotonated forms of $(E)-4-[(2-$ hydroxybenzylideneamino)pyrimidin-2(1H)-one, was reported. The structure of the complex was confirmed by various spectroscopic tools, such as FT-IR, NMR, UV-Vis, mass, spectrometry, elemental analyses, magnetic susceptibilities and thermal analysis. After characterized of $\mathrm{Zn}$ (II) complex, we examined the cytotoxic effects of 5-FU and $\mathrm{Zn}$ (II) complex alone or in combination with EP on U118 and T98G human brain tumor cell lines. Furthermore, biocompatibility characteristics of the compounds were determined in the healthy HDF cell line.

\section{Materials And Methods}

\section{Chemical compounds and measurements}

All chemical reagents and solvents were of analytical grade and were obtained from Sigma-Aldrich. Microanalyses $(\mathrm{C}, \mathrm{H}, \mathrm{N})$ data were obtained using a Carlo Erba model 1106 elemental analyzer. Infrared spectra (4000-400 $\mathrm{cm}^{-1}, \mathrm{KBr}$ discs) were recorded on a Perkin Elmer 65 spectrometer. Magnetic susceptibilities of the complex (Gouy's method) were measured using a Sherwood Scientific magnetic balance. Electronic spectra were measured on an Agilent-Carry 60 spectrophotometer using matched quartz cuvettes were used for measurements. Nuclear magnetic resonance (NMR) measurements were carried out on a Bruker-300 MHz spectrometer using DMSO- $\mathrm{d}_{6}$ solvent. Mass spectra of solid complexes (70 eV, EI) were performed on a Bruker microflex LT MALDI-TOF MS spectrometer. Thermogravimetric (TG) analyses were done under stream of nitrogen gas $\left(10^{\circ} \mathrm{C} / \mathrm{min}\right)$ using a Shimadzu DT-50 thermal analyzer.

\section{Synthesis and characterization of Schiff base-Zn(II) complex}

(E)-4-[(2-hydroxybenzylideneamino)pyrimidin-2(1 H)-one (L) $(0.34 \mathrm{~g}, 1.58 \mathrm{mmoL}$ in $15 \mathrm{~mL}$ methanol) was mixed with $\mathrm{ZnCl}_{2}(0.31 \mathrm{~g}, 3.15 \mathrm{mmol}$ in $15 \mathrm{~mL}$ methanol). The resulted mixture was stirred and heated under reflux for $5 \mathrm{~h}$. The separated complex was collected by filtration, washed thoroughly with methanol, ether. It was then crystallized in methanol/chloroform (1/2) and finally dried in a vacuum over fused $\mathrm{CaCl}_{2}$. The structure of $\mathrm{Zn}(\mathrm{II})$ complex was shown in Fig. 1. Yield $82 \%, \mathrm{mp} 305^{\circ} \mathrm{C}$. Color: White. Anal. Calcd. for $\left(\mathrm{C}_{22} \mathrm{H}_{18} \mathrm{~N}_{6} \mathrm{O}_{5} \mathrm{Zn}_{2} \mathrm{Cl}_{2}\right.$ ) (FW: $648.08 \mathrm{~g} / \mathrm{mol}$ ) (\%): C; 40.77, $\mathrm{H} ; 2.79, \mathrm{~N} ; 12.96$. Found: $\mathrm{C} ; 40.74, \mathrm{H}$; 2.75, N; 13.00. FT-IR (KBr, U max (cm-1)): 3430, 3373, $3320(\mathrm{OH}), 3165(\mathrm{NH}), 3088,3032(\mathrm{Ar}-\mathrm{CH}), 2963$, 2899 (Alip-CH), 1720 (C=O), $1636(\mathrm{CH}=\mathrm{N}), 1655$ ( $\left.\mathrm{CH}=\mathrm{N}_{\text {pyrimidine ring }}\right), 1564,1537,1454(\mathrm{Ar}-\mathrm{C}=\mathrm{C}), 1266$ (C-0), 584-523 (M-O), 506, 470, $461(\mathrm{M}-\mathrm{N}) .{ }^{1} \mathrm{H}-\mathrm{NMR}\left(300 \mathrm{MHz}, \mathrm{DMSO}_{\mathrm{d}}\right)$ : $\delta(\mathrm{ppm})=8.34(\mathrm{~s}, \mathrm{H}, \mathrm{N}=\mathrm{CH})$,

$8.04(\mathrm{~s}, \mathrm{H}, \mathrm{NH}), 7.52-5.81(\mathrm{~m}, 5 \mathrm{H}, \mathrm{Ar}-\mathrm{H}), 3.86$ (d, Ar- $\left.\mathrm{H}_{\text {pyrimidine ring }}\right) .{ }^{13} \mathrm{C}-\mathrm{NMR}\left(75 \mathrm{MHz}, \mathrm{DMSO}-\mathrm{d}_{6}\right): \delta(\mathrm{ppm})$ $=163.94(\mathrm{C}=0), 161.41(\mathrm{CH}=\mathrm{N}), 156.29(\mathrm{C}-\mathrm{OH}), 157.16(\mathrm{C}-\mathrm{N}), 140.17-100.01(\mathrm{Ar}-\mathrm{C})$. UV-Vis bands $(\lambda \max , \mathrm{nm})\left(\varepsilon, \mathrm{M}^{-1} \mathrm{~cm}^{-1}\right): 220$ (3463), 230 (3504), 275 (3456), 335 (95), 430 (53), 495 (39). Mass spectrum [ESI], $m / z$ : 629.06 (calcd.), 629.16 (found) [M- $\left.\mathrm{H}_{2} \mathrm{O}-\mathrm{H}\right]^{+}$.

\section{Cell lines and culture}


U118 (RRID: CVCL_0633) and T98G (RRID: CVCL_0556) originated a human brain glioma and HDF (Human Dermal Fibroblast) were obtained from the American Type Culture Collection (ATCC, Rockville, USA). The cells were kept in $75 \mathrm{~cm} 2$ flasks of Dulbecco's Modified Eagle's Medium (DMEM) containing $100 \mathrm{U} / \mathrm{mL}$ Penstrep and $10 \% \mathrm{FBS}$ at $37^{\circ} \mathrm{C}$ with $5 \% \mathrm{CO} 2,95 \%$ air, and complete humidity.

\section{Chemotherapy}

Once the cells reached $\sim 80 \%$ confluency, they were detached using trypsin/EDTA and counted by hemocytometer and $0.4 \%$ Trypan Blue was used to determine the viability rate. All the experiments were carried out at the viability rate of $90 \%$ or more. $1 \times 10^{4}$ cells for U118 and T98G and $5 \times 10^{3}$ cells for HDF were plated into each well of 96 well-plate and incubated at $37^{\circ} \mathrm{C}$ for $24 \mathrm{~h}$. Then, the medium were removed and $100 \mu \mathrm{L}$ of $\mathrm{Zn}$ (II) complex and 5-FU solution (at the concentrations of 50, 100, 200, 300, 400, and $500 \mu \mathrm{M}$ ) prepared in the culture medium were added to the wells, and the cells were incubated for 24 $\mathrm{h}$ again. The concentrations were kept the same in all the MTT tests. Only $100 \mu \mathrm{L}$ of Dulbecco's Modified Eagle Medium (culture medium) was added to the control wells [21].

\section{Establishment of efficient electroporation (EP) protocols}

Cell viability and PI uptake determine how efficient an EP protocol is. Cell viability refers to the ratio of the cells able to remain undamaged and metabolically active after the electrical field is applied. After the T98G and U118 cells reached a confluence of $70 \%-80 \%$, they were removed using Trypsin/EDTA solution (Invitrogen) and centrifuged for $5 \mathrm{~min}$ at $1000 \mathrm{rpm}$ for precipitation. $10 \mu \mathrm{L}$ propidium iodide (PI) was added to the cell suspension $(90 \mu \mathrm{L})$ with a density of $1 \times 10^{6}$ cell/ $\mathrm{mL}$ and put into EP cuvettes with $4 \mathrm{~mm}$ gap (BTX) for determining the cell electropermeabilization. Depending on how permeable the cells are, propidium iodide permeates the cells and emits red fluorescent. With the purpose of determining the cell mortality caused by the electric pulses, $400 \mu \mathrm{L}$ cell suspension at the density of $1 \times 10^{6} \mathrm{cell} / \mathrm{mL}$ was added into the $4 \mathrm{~mm}$ EP cuvettes, which were put separately into the chamber of BTX Gemini X ${ }^{2}$ EP device (Harvard Apparatus, USA). Then, 8 square-wave pulses (electric field intensity: 0-1500 V/cm, frequency: 1 $\mathrm{Hz}$, pulse duration: $100 \mu \mathrm{s}$ ) were applied to all cells except the control cells. After the electric field application, the cells were left for incubation at room temperature for $15 \mathrm{~min}$. A fluorescence microscopy was used to observe the electropermeabilization and the MTT analysis method was used to determine the cell viability.

\section{Electrochemotherapy protocol}

After reaching a confluence of $70 \%-80 \%$, the T98G and U118 cells were harvested using $0.05 \%$ trypsin and counted, then $1 \times 10^{6}$ cells $/ \mathrm{mL}$ were suspended again in $400 \mu \mathrm{L}$ of Dulbecco's Modified Eagle Medium (DMEM) with/without 5-FU and Zn(II) complex in $4 \mathrm{~mm}$ EP cuvettes (BTX). 5-FU and Zn(II) complex were added into the cell suspension before the EP at the concentrations of $25,50,100$, and $200 \mu \mathrm{M}$. 8 squarewave electric pulses (frequency: $1 \mathrm{~Hz}$, pulse duration: $100 \mu \mathrm{s}$ ) were applied to the T98G cells at 1000 $\mathrm{V} / \mathrm{cm}$ and the $\mathrm{U} 118$ cells at $1250 \mathrm{~V} / \mathrm{cm}$ in line with the ECT therapy clinical practices [22,23]. The EP 
parameters used in the ECT were optimized to reach a high level of permeabilization and a low level of cellular mortality by EP alone using the PI uptake and MTT assay. The cells that were subjected to the compound applications alone were also put in the EP cuvettes for the same duration and under the same conditions, but no voltage was applied. All the experiments were carried out in 4 replications.

After the EP, the cells were left for incubation for $15 \mathrm{~min}$ at room temperature and seeded on the plates with 96 wells and again left for incubation. After a 24 hours incubation, the ECT efficiency was assessed based on a cell viability analysis carried out using an MTT assay [24].

\section{MTT analysis}

$\mathrm{Zn}$ (II) complex and 5-FU were applied to the cells alone or in combination with EP for 24 hours, and the cell viability was measured using an MTT (3-(4,5-dimethylthiazol-2-yl)-2,5-diphenyltetrazolium bromide) assay. After the chemotherapy and ECT, the cells were seeded into the plates and incubated with $5 \% \mathrm{CO}_{2}$ at a humidity of $95 \%$ for $24 \mathrm{~h}$ at $37^{\circ} \mathrm{C}$. After the incubation, the substance solutions in the wells were taken, $90 \mu \mathrm{L}$ DMEM and $10 \mu \mathrm{L}$ MTT solution were added, and the cells were incubated again for another $4 \mathrm{~h}$. After the second incubation, the growth medium with MTT was removed from the medium, and 100 $\mu \mathrm{L}$ dimethyl sulfoxide (DMSO) was added to the wells to dissolve the formazan crystals in the wells. The optical density (OD) of the color intensity was measured using a spectrophotometer at $570 \mathrm{~nm}$ [25]. Only the fresh medium was used as the control. Because light affects MTT, the experiments were carried out in dark. The absorbance values of the groups subjected to the compounds were proportioned to the absorbance value of the control, and \% viability was computed using the formula below.

$\%$ Viability $=(O D$ of the group subjected to the compound $/ O D$ of the control group $) \times 100$

Median inhibitory concentration $\left(\mathrm{IC}_{50}\right)$ refers to the concentration that exerts an inhibitory effect of $50 \%$ on the cell proliferation. $\mathrm{IC}_{50}$ values were estimated via the regression equation created using the doseresponse curve. The cytotoxicity of the $5-\mathrm{FU}$ and $\mathrm{Zn}(\mathrm{II})$ complex against the cancer cells and their safety toward the normal cells were calculated using the ratio of the $\mathrm{IC}_{50}$ for the normal cells (HDF) to the $\mathrm{IC}_{50}$ for the cancer cells (T98G and U118). All the analyses were carried out in 3 parallels. Mean \pm standard deviation was used to express the results.

\section{Statistical analysis}

Graph Pad Prism software (Graph Pad Software Inc., San Diego, USA) was used to conduct the statistical analyses. The data are given as mean \pm standard deviation (SD), and all of the experiments were carried out in triplicate. $p<0.05$ was chosen as the statistical significance level.

\section{Results And Discussion}

\section{Chemical}


The infrared spectra of the prepared Schiff base-Zn(II) complex were measured in $\mathrm{KBr}$ disc and significant FT-IR spectral assignments were shown in the experimental section. Water molecules could be estimated by the characteristic vibrational band at 3430,3373 and $3320 \mathrm{~cm}^{-1}$ for $\mathrm{Zn}$ (II) complex as coordinated labile solvent molecules. The shifts in the bands of some functional groups, such as $\mathrm{HC}=\mathrm{N}$, $\mathrm{C}=\mathrm{O}$ and $\mathrm{N}-\mathrm{H}$ toward high wavenumber indicated that the ligands coordinated to zinc ion from their $\mathrm{O}$ and $\mathrm{N}$ donor atoms $[26,27]$. For ligand, the $\mathrm{v}(\mathrm{C}-0)$ appeared at $1275 \mathrm{~cm}^{-1}$ while for complex it was shifted to $1266 \mathrm{~cm}^{-1}$ may be due to the coordination oxygen atom to metal ion [28]. The bands in the spectra of the $\mathrm{Zn}$ (II) complex in the ranges $584-523 \mathrm{~cm}^{-1}$ and $506-461 \mathrm{~cm}^{-1}$ were attributed to $\mathrm{v}(\mathrm{M}-\mathrm{O})$ and $\mathrm{v}(\mathrm{M}-\mathrm{N})$ stretching frequencies indicating coordination of the Schiff base to the respective metal ion [2,29].

The ${ }^{1} \mathrm{H}$ and ${ }^{13} \mathrm{C}$ NMR spectra of diamagnetic $\mathrm{Zn}(\mathrm{II})$ complex recorded in $\mathrm{d}_{6}$-dimethylsulfoxide (DMSO- $\mathrm{d}_{6}$ ) solution using tetramethylsilane $\left(\mathrm{Me}_{4} \mathrm{Si}\right)$ as internal standard The chemical shift observed for the $\mathrm{OH}$ proton in the ligand (10.58 ppm) was not observed in the $\mathrm{Zn}$ (II) complex. Disappearance of the significant singlet signal of phenolic $\mathrm{OH}$ in the ligand could interpret the complexation of the ligand with phenolic $\mathrm{OH}$ via deprotonation. The ${ }^{13} \mathrm{C}$ NMR spectra of the $\mathrm{Zn}$ (II) complex showed the presence of azomethine $(\mathrm{CH}=\mathrm{N})$ downfield at $161.41 \mathrm{ppm}$ and consistent with the ${ }^{1} \mathrm{H}$ NMR peak at $8.34 \mathrm{ppm}$. This confirms the presence of azomethine functionality. The same results were confirmed by the IR spectra. The aromatic carbons were assigned to signals at $140.17-100.01 \mathrm{ppm}$. The signal for carbonyl carbon was observed downfield at $163.94 \mathrm{ppm}$. All assignments support the structure of the synthesized compound.

The electronic spectra of the $\mathrm{Zn}$ (II) complex reveal intense absorption bands at 220-275 $\mathrm{nm}$ attributable to $\pi \rightarrow \pi^{*}$ transitions of the benzene rings. The absorption band at $335 \mathrm{~nm}$ for the complex was assigned to $n \rightarrow \pi^{*}$ transition of the azomethine groups and oxygen atoms. The bands observed at $430 \mathrm{~nm}$ and 495 $\mathrm{nm}$ in the spectra of the complex were assigned to charge transfer transitions. The new visible bands could be evidence for the complex formation between ligand and $\mathrm{Zn}^{2+}$ ion. The presence of the ligand for bidentate chelation in the $\mathrm{Zn}$ (II) complex may due to the presence of zinc ion for tetrahedral coordination [30-32].

The $\left[\mathrm{ZnL}_{2}\right] \mathrm{Cl}_{2} \mathrm{H}_{2} \mathrm{O}$ complex decomposed from temperature 100 to $800^{\circ} \mathrm{C}$ with two steps as follows. The first step occurred within the temperature range of $100-420{ }^{\circ} \mathrm{C}$ with maximum temperature at $342{ }^{\circ} \mathrm{C}$ and correspond to the elimination of one water molecule, chloride and a part of ligand molecule $\left(\mathrm{C}_{4} \mathrm{H}_{4}\right)$ with a found mass loss of $22.20 \%$ (calc. $21.74 \%$ ). The second step represented the loss of the $\mathrm{C}_{18} \mathrm{H}_{12} \mathrm{~N}_{6}$ molecule with a mass loss of $48.41 \%$ (calc. $48.14 \%$ ) and the temperature range $420-800{ }^{\circ} \mathrm{C}$. As a final stage; it left air stable metal oxide as a residue.

Mass spectra showed the correct molecular ion as suggested by its molecular formulae. All the data for the zinc complex are in agreement with those reported for similar complexes [33,34].

\section{Optimal EP parameters}


A fluorescence microscopy was used to observe the electropermeabilization of the U118 and T98G cells based on the PI uptake. Based on the fluorescent intensity of the PI in the cells, it was found that the number of permeabilized cells increased with the increase in the strength of the electric field (Fig. 2). Electric field intensities above $1 \mathrm{kV} / \mathrm{cm}$ for T98G and $1250 \mathrm{~V} / \mathrm{cm}$ for $\mathrm{U} 118$ provided very good membrane permeabilization. In order to determine the appropriate voltage for $E P$, it is necessary to evaluate cell viability along with electropermeabilization.

To determine the cell mortality caused by the electric pulses, cells were exposed to the same values of electric field intensities $(0,250 \mathrm{~V} / \mathrm{cm}, 500 \mathrm{~V} / \mathrm{cm}, 750 \mathrm{~V} / \mathrm{cm}, 1000 \mathrm{~V} / \mathrm{cm}, 1250 \mathrm{~V} / \mathrm{cm}$, and $1500 \mathrm{~V} / \mathrm{cm})$ used in electropermeabilization and left for incubation. After 24 hours of incubation, cell viability was determined by the MTT analysis method (Fig. 3).

The cell viability decreased proportionally to the amplitude of the electric pulses. As can be seen in Fig. 3 , a sharp decrease in cell viability was observed after $1000 \mathrm{~V} / \mathrm{cm}$ in the T98G cell line, while a high level of decrease in cell viability was observed in the $U 118$ cell line after $1250 \mathrm{~V} / \mathrm{cm}$. In this study, based on the results of the cell viability test and electropermeabilization analysis, the electric field intensities were chosen as $1000 \mathrm{~V} / \mathrm{cm}$ for T98G and $1250 \mathrm{~V} / \mathrm{cm}$ for U118. These values are ideal for the ECT (EP+compound).

\section{Chemotherapy and electrochemotherapy}

First of all, we examined the inhibitory effects of the $\mathrm{Zn}$ (II) complex and 5-FU alone at various concentrations $(50,100,200,300,400$, and $500 \mu \mathrm{M})$ after a treatment of 24 hours. Second, we examined the combined effect of EP + 5-FU or Zn(II) complex. The inhibition values (\%) of the cells were computed using the absorbance values measured by a spectrophotometer. MTT assay was used to determine the inhibition in the proliferation of the cells. The $\mathrm{IC}_{50}$ values were calculated for each cell line and summarized in Table 1.

\section{Table 1}

$\mathrm{IC}_{50}$ values of the $\mathrm{Zn}(\mathrm{II})$ and 5-FU in T98G, U118 and HDF cells

\begin{tabular}{|llll|}
\hline Compounds & T98G & U118 & HDF \\
& $\mathrm{IC}_{50}(\mu \mathrm{M})$ & $\mathrm{IC}_{50}(\mu \mathrm{M})$ & $\mathrm{IC}_{50}(\mu \mathrm{M})$ \\
\hline $\mathrm{Zn}(\mathrm{II})$ & 282.47 & 297.91 & 826.72 \\
\hline $5-\mathrm{FU}$ & 382.35 & 396.56 & 868.7 \\
\hline $\mathrm{Zn}(\mathrm{II})+\mathrm{EP}$ & 47.41 & 62.54 & - \\
\hline 5-FU +EP & 90.43 & 103.31 & - \\
\hline
\end{tabular}


The lower the $\mathrm{IC}_{50}$, the higher the cytotoxicity. According to IC $\mathrm{C}_{50}$ values, $\mathrm{Zn}$ (II) complex showed good cytotoxicity against T98G and U118 brain cancer cell lines with $\mathrm{IC}_{50}=282.47$ and $297.91 \mu \mathrm{M}$ respectively, while it was safe on HDF healthy cells with $\mathrm{IC}_{50}=826.72 \mu \mathrm{M}$. As seen in the Table 1 , in general, $\mathrm{Zn}$ (II) complex exhibited a better cytotoxicity than 5-FU, a standard chemotherapy drug, on both brain cancer cell lines (T98G and U118).

The EP in combination with either drug caused a significant decrease in the $\mathrm{IC}_{50}$ values for both brain cancer cell lines $(p<0.0001)$. As seen in the Table 1 and Fig. 4, in ECT (EP + 5-FU or Zn), the newly synthesized Zn(II) complex was found to have a higher anticancer activity against both brain cancer cell lines (U118 and T98G) than 5-FU. ECT is a local treatment and not applied to the healthy cells normally; therefore, in this study, EP was not applied to the healthy fibroblast cells (HDF).

Glioblastoma is known to be the most aggressive and malignant brain tumor. It has a heterogeneity in terms of genotype and phenotype, and moreover, no precise treatment model has been developed yet. Today, TMZ is the standard chemotherapeutic drug for the patients with glioblastoma; however, glioblastoma cells resist TMZ chemotherapy [35]. Therefore, there is an urgent need for developing novel treatment options with new drugs that offer a low toxicity but a high efficacy and selectively target the tumor cells in brain tumors resistant to therapy. Zinc, an essential metal, functions as a cofactor of many enzymes. The relationship between cancer and zinc deficiency has attracted the attention of researchers who work on novel metal drugs. Previous studies suggest that Zn-containing compounds might be useful in the treatment of cancer. $\mathrm{Zn}$ (II) complexes are able to kill cancer cells by means of triggering cell apoptosis and targeting DNA or other components in the nucleus [36].

In the present study, Zn(II) complex was found to have a good cytotoxicity against both glioblastoma cancer cell lines (T98G and U118), whereas it was found to be safe on the HDF healthy cells. Moreover, the $\mathrm{Zn}$ (II) complex was found to show a better cytotoxicity than 5-FU (Table 1). The chemotherapeutic drugs have to show the ability to kill the tumor cells but not the healthy cells. To this end, researchers across the world have been putting effort into discovering and developing a chemotherapeutic drug that features a high selectivity and kills tumor cells without harming the normal cells [37]. In study, the Zn(II) complex displayed a powerful selectivity toward the glioblastoma cell lines. Metal complexes like Zn(II) may enter the cancer cell, permeate the nucleus, mitochondria, cytoplasm, and exert their anti-tumor effect. Previous studies mostly focused on DNA interactions, although TOPO-III, p53, nuclease were reported to be the alternative targets [15]. We are of the opinion that there is a need for detailed studies to determine the potential targets of $\mathrm{Zn}$ (II) complexes.

Chemotherapy plays a key role in the treatment of glioblastoma; however, chemotherapeutic resistance decreases its effectiveness [38]. The drug resistance seen in cancer cells and the resistance of cell membrane to the chemotherapeutic agents cause that the treatment takes a longer time and the side effects increase due to the medication at high doses [39]. On the other hand, ECT offers an effective treatment with very low doses of chemotherapy drugs in a short time and, by doing so, minimizes the side effects associated with the treatment. Applying electrical impulses to the cells in combination with 
cytotoxic agents enhances the permeability of the cell membrane and thus facilitates the transport of the chemotherapeutic agents to the cells [40]. The type, frequency, duration, amplitude and number of the electrical pulses change the cell permeability and, accordingly, the effectiveness of ECT $[40,41]$. Therefore, it is of great importance to choose the optimum electrical parameters for ECT. In this study, the optimum EP parameters were found to be $1000 \mathrm{~V} / \mathrm{cm}$ and $1250 \mathrm{~V} / \mathrm{cm}$ (frequency: $1 \mathrm{~Hz}$, pulse duration: $100 \mu \mathrm{s}$, and number of pulses: 8) for the T98G and U118 cell lines, respectively.

In the ECT treatment, $\mathrm{Zn}$ (II) complex displayed a high cytotoxicity against the T98G and U118 cells with the $\mathrm{IC}_{50}$ values of 47.41 and $62.54 \mu \mathrm{M}$, respectively. Moreover, 5 -FU+EP caused a significant decrease in the viability of T98G and U118 cells with the $\mathrm{IC}_{50}$ values of 90.43 and $103.31 \mu \mathrm{M}$, respectively. These results showed that EP increased the cytotoxicity of the 5-FU and $\mathrm{Zn}$ (II) complex in both cell lines. However, the newly synthesized Zn(II) complex showed much higher anticancer activity in this treatment method compared to the standard anticancer drug 5-FU. DNA is the most important target for anticancer drugs in the cell [42]. ECT might have helped the Zn(II) complex and 5-FU to reach cells and damage the DNA by means of enhancing the intra-cellular concentrations. The interaction between the agent and DNA might result in DNA fragmentation and cell death. Thanks to the permeability provided by EP, a lower dose of an anticancer drug applied for a shorter time can be enough for an effective therapy, which minimizes the adverse effects seen in chemotherapy. In previous studies, it was reported that the electrical pulses used in ECT also regulated the blood flow of tumor and caused a decrease in the blood flow of tumor and partial oxygen pressure $\left(\mathrm{pO}_{2}\right)$ [43]. As a result, the efficacy of anticancer agents increases. Because anticancer agents stay inactive in the cells that have abundant oxygen [44]. Several in-vitro and in-vivo studies on various chemotherapeutic drugs have shown that ECT is an effective method [17,45].

\section{Conclusion}

A new zinc(II) complex was prepared and structurally characterized. The results showed that the stoichiometry in the complex is 2:1 (metal:ligand). In vitro anticancer activities of the 5-FU and newly synthesized Zn(II) complex were evaluated on the two human brain tumor cell lines (T98G, U118) and biocompatibility characteristics were determined in the HDF fibroblast cell line by using the MTT assay. Furthermore, we examined the effectiveness of EP on cytotoxic activities of these compounds in the T98G and U118 cell lines. The results of the present study revealed that Zn(II) complex had an anticancer potential against the T98G and U118 brain tumor cell lines, and EP increased the anticancer effect of $\mathrm{Zn}$ (II) complex and 5-FU. Moreover, it was found that application of Zn(II) complex alone or in combination with EP showed a higher cytotoxicity than 5-FU in these cell lines. This research could lead to new treatment options for chemotherapy-resistant brain tumor cells. More in-vitro and in-vivo research is needed for probable clinical translation.

\section{Declarations}


The authors declare that they have no known competing financial interests or personal relationships that could have appeared to influence the work reported in this paper.

\section{Funding}

This research did not receive any specific grant from funding agencies in the public, commercial, or notfor-profit sectors

\section{References}

1. Naureen B, Miana GA, Shahid K, Asghar M, Tanveer S, Sarwar A. Iron (III) and zinc (II) monodentate Schiff base metal complexes: Synthesis, characterisation and biological activities. J Mol Struct. 2021;1231(129946):129946. https://doi.org/10.1016/j.molstruc.2021.129946.

2. Rauf A, Shah A, Khan AA, Shah AH, Abbasi R, Qureshi IZ, et al. Synthesis, pH dependent photometric and electrochemical investigation, redox mechanism and biological applications of novel Schiff base and its metallic derivatives. Spectrochim Acta A Mol Biomol Spectrosc. 2017;176:15567. https://doi.org/10.1016/j.saa.2017.01.018.

3. Cozzi PG. Metal-Salen Schiff base complexes in catalysis: practical aspects. Chem Soc Rev. 2004;33(7):410-21. https://doi.org/10.1039/B307853C.

4. Gan K-C, Sim K-M, Lim T-M, Teo K-C. Synthesis, cytotoxic, antibacterial and free radical scavenging activities of Schiff bases derived from 1,2,4-triazole. Lett Org Chem. 2019;16(12):9961003. http://dx.doi.org/10.2174/1570178616666190315154512.

5. Nejo AA, Kolawole GA, Nejo AO. Synthesis, characterization, antibacterial, and thermal studies of unsymmetrical Schiff-base complexes of cobalt(II). J Coord Chem. 2010;63(24):4398410. http://dx.doi.org/10.1080/00958972.2010.532871.

6. Taha RH, El-Shafiey ZA, Salman AA, El-Fakharany EM, Mansour MM. Synthesis and characterization of newly synthesized Schiff base ligand and its metal complexes as potent anticancer. J Mol Struct. 2019;1181:536-45. https://doi.org/10.1016/j.molstruc.2018.12.055.

7. Ajibade PA, Andrew FP, Botha NL, Solomane N. Synthesis, crystal structures and anticancer studies of morpholinyldithiocarbamato $\mathrm{Cu}(\mathrm{II})$ and $\mathrm{Zn}$ (II) complexes. Molecules. 2020;25(16):3584. http://dx.doi.org/10.3390/MOLECULES25163584

8. Wang H, Zhou H, Xu J, Lu Y, Ji X, Yao Y, et al. Different T-cell subsets in glioblastoma multiforme and targeted immunotherapy. Cancer Lett. 2021;496:134-

43. http://dx.doi.org/10.1016/J.CANLET.2020.09.028.

9. Mazor G, Levin L, Picard D, Ahmadov U, Carén H, Borkhardt A, et al. The IncRNA TP73-AS1 is linked to aggressiveness in glioblastoma and promotes temozolomide resistance in glioblastoma cancer stem cells. Cell Death Dis. 2019;10(3). http://dx.doi.org/10.1038/S41419-019-1477-5.

10. Țigu AB, Toma V-A, Moț AC, Jurj A, Moldovan CS, Fischer-Fodor E, et al. The synergistic antitumor effect of 5-fluorouracil combined with allicin against lung and colorectal carcinoma cells. Molecules. 
2020;25(8):1947. http://dx.doi.org/10.3390/MOLECULES25081947.

11. Longley DB, Harkin DP, Johnston PG. 5-Fluorouracil: mechanisms of action and clinical strategies. Nat Rev Cancer. 2003;3(5):330-8. http://dx.doi.org/10.1038/NRC1074.

12. Yang H, Huang $S$, Wei $Y$, Cao S, Pi C, Feng T, et al. Curcumin enhances the anticancer effect of 5fluorouracil against gastric cancer through down-regulation of COX-2 and NF- KB signaling pathways. J Cancer. 2017;8(18):3697-706. http://dx.doi.org/10.7150/JCA.20196.

13. Popović A, Nikolić M, Mijajlović M, Ratković Z, Jevtić V, Trifunović SR, et al. DNA binding and antitumor activities of zinc(II) complexes with some S-alkenyl derivatives of thiosalicylic acid. Transit Met Chem. 2019;44(3):219-28. http://dx.doi.org/10.1007/S11243-018-0285-6.

14. Kovala-Demertzi D, Alexandratos A, Papageorgiou A, Yadav PN, Dalezis P, Demertzis MA. Synthesis, characterization, crystal structures, in vitro and in vivo antitumor activity of palladium(II) and zinc(II) complexes with 2-formyl and 2-acetyl pyridine N(4)-1-(2-pyridyl)-piperazinyl thiosemicarbazone. Polyhedron. 2008;27(13):2731-8. https://doi.org/10.1016/j.poly.2008.04.009.

15. Porchia M, Pellei M, Del Bello F, Santini C. Zinc complexes with nitrogen donor ligands as anticancer agents. Molecules. 2020;25(24):5814. http://dx.doi.org/10.3390/MOLECULES25245814.

16. Mendiguchia BS, Pucci D, Mastropietro TF, Ghedini M, Crispini A. Non-classical anticancer agents: on the way to water soluble zinc(ii) heteroleptic complexes. Dalton Trans. 2013;42(19):6768. http://dx.doi.org/10.1039/C3DT50367D.

17. Kranjc S, Cemazar M, Sersa G, Scancar J, Grabner S. In vitro and in vivo evaluation of electrochemotherapy with trans-platinum analogue trans-[PtCl2(3-Hmpy)2]. Radiol Oncol. 2017;51(3):295-306. http://dx.doi.org/10.1515/RAON-2017-0034.

18. Fiorentzis M, Kalirai H, Katopodis P, Seitz B, Viestenz A, Coupland SE. Electrochemotherapy with bleomycin and cisplatin enhances cytotoxicity in primary and metastatic uveal melanoma cell lines in vitro. Neoplasma. 2018;65(02):210-5. http://dx.doi.org/10.4149/NEO_2018_170329N227.

19. Probst U, Fuhrmann I, Beyer L, Wiggermann P. Electrochemotherapy as a new modality in interventional oncology: A review. Technol Cancer Res Treat.

2018;17:153303381878532. http://dx.doi.org/10.1177/1533033818785329.

20. Linnert M, Agerholm-Larsen B, Mahmood F, Iversen HK, Gehl J. Electrochemotherapy for primary and secondary brain tumors. In: Tumors of the Central Nervous system, Volume 3. Dordrecht: Springer Netherlands; 2011. p. 195-206. http://dx.doi.org/10.1007/978-94-007-1399-4_20.

21. Alkış ME, Keleştemür Ü, Alan Y, Turan N, Buldurun K. Cobalt and ruthenium complexes with pyrimidine based schiff base: Synthesis, characterization, anticancer activities and electrochemotherapy efficiency. J Mol Struct. 2021;1226(129402):129402. http://dx.doi.org/10.1016/J.MOLSTRUC.2020.129402.

22. Campana LG, Miklavčič D, Bertino G, Marconato R, Valpione S, Imarisio I, et al. Electrochemotherapy of superficial tumors - Current status: Semin Oncol. 2019;46(2):17391. http://dx.doi.org/10.1053/J.SEMINONCOL.2019.04.002. 
23. Sersa G, Cemazar M, Snoj M. Electrochemotherapy of tumours. Curr Oncol. 2009;16(2):345. https://www.ncbi.nlm.nih.gov/pmc/articles/PMC2669236.

24. Kumar P, Nagarajan A, Uchil PD. Analysis of cell viability by the MTT assay. Cold Spring Harb Protoc. 2018;2018(6):db.prot095505. http://dx.doi.org/10.1101/pdb.prot095505.

25. Mahajan SD, Law W-C, Aalinkeel R, Reynolds J, Nair BB, Yong K-T, et al. Nanoparticle-mediated targeted delivery of antiretrovirals to the brain. In: Methods in Enzymology. Elsevier; 2012. p. 4160. http://dx.doi.org/10.1016/b978-0-12-391858-1.00003-4.

26. Kargar H, Ardakani AA, Tahir MN, Ashfaq M, Munawar KS. Synthesis, spectral characterization, crystal structure determination and antimicrobial activity of $\mathrm{Ni}(\mathrm{II}), \mathrm{Cu}(\mathrm{II})$ and $\mathrm{Zn}(\mathrm{II})$ complexes with the Schiff base ligand derived from 3,5-dibromosalicylaldehyde. J Mol Struct. 2021;1229(129842):129842. https://doi.org/10.1016/j.molstruc.2020.129842.

27. Yousef TA, Abu El-Reash GM, El Morshedy RM. Quantum chemical calculations, experimental investigations and DNA studies on (E)-2-((3-hydroxynaphthalen-2-yl)methylene)-N-(pyridin-2yl)hydrazinecarbothioamide and its $\mathrm{Mn}(\mathrm{II}), \mathrm{Ni}(\mathrm{II}), \mathrm{Cu}(\mathrm{II}), \mathrm{Zn}(\mathrm{II})$ and $\mathrm{Cd}(\mathrm{II})$ complexes. Polyhedron. 2012;45(1):71-85. http://dx.doi.org/10.1016/j.poly.2012.07.041.

28. El-Sawaf AK, El-Essawy F, Nassar AA, El-Samanody E-SA. Synthesis, spectral, thermal and antimicrobial studies on cobalt(II), nickel(II), copper(II), zinc(II) and palladium(II) complexes containing thiosemicarbazone ligand. J Mol Struct. 2018;1157:38194. https://doi.org/10.1016/j.molstruc.2017.12.075.

29. El-Medani SM, Makhlouf AA, Moustafa H, Afifi MA, Haukka M, Ramadan RM. Spectroscopic, crystal structural, theoretical and biological studies of phenylacetohydrazide Schiff base derivatives and their copper complexes. J Mol Struct. 2020;1208(127860):127860. http://dx.doi.org/10.1016/J.MOLSTRUC.2020.127860.

30. Spînu C, Pleniceanu M, Tigae C. Biologically active new Fe(II), Co(II), Ni(II), Cu(II), Zn(II) and Cd(II) complexes of N-(2-thienylmethylene)methanamine. J Serb Chem Soc. 2008;73(4):41521. http://dx.doi.org/10.2298/JSC0804415S.

31. Jeslin Kanaga Inba P, Annaraj B, Thalamuthu S, Neelakantan MA. Cu(II), Ni(II), and Zn(II) complexes of Salan-type ligand containing ester groups: Synthesis, characterization, electrochemical properties, andln VitroBiological activities. Bioinorg Chem Appl. 2013;2013:111. https://doi.org/10.1155/2013/439848.

32. Etaiw SEH, Abd El-Aziz DM, Abd El-Zaher EH, Ali EA. Synthesis, spectral, antimicrobial and antitumor assessment of Schiff base derived from 2-aminobenzothiazole and its transition metal complexes. Spectrochim Acta A Mol Biomol Spectrosc. 2011;79(5):13317. http://dx.doi.org/10.1016/j.saa.2011.04.064.

33. Rauf A, Shah A, Munawar KS, Ali S, Nawaz Tahir M, Javed M, et al. Synthesis, physicochemical elucidation, biological screening and molecular docking studies of a Schiff base and its metal(II) complexes. Arab J Chem. 2020;13(1):1130-41. http://dx.doi.org/10.1016/J.ARABJC.2017.09.015. 
34. Revathi N, Sankarganesh M, Rajesh J, Raja JD. Biologically active cu(II), co(II), Ni(II) and Zn(II) complexes of pyrimidine derivative Schiff base: DNA binding, antioxidant, antibacterial and in vitro anticancer studies. J Fluoresc. 2017;27(5):1801-14. http://dx.doi.org/10.1007/s10895-017-2118-y.

35. Lee SY, Slagle-Webb B, Rizk E, Patel A, Miller PA, Sung S-S, et al. Characterization of a novel anticancer compound for astrocytomas. PLoS One. 2014;9(9):e108166. http://dx.doi.org/10.1371/JOURNAL.PONE.0108166.

36. Yu P, Deng J, Cai J, Zhang Z, Zhang J, Hamid Khan M, et al. Anticancer and biological properties of a Zn-2,6-diacetylpyridine bis(thiosemicarbazone) complex. Metallomics. 2019;11(8):137286. https://doi.org/10.1039/c9mt00124g.

37. Arafath MA, Adam F, Razali MR, Ahmed Hassan LE, Ahamed MBK, Majid AMSA. Synthesis, characterization and anticancer studies of $\mathrm{Ni}(\mathrm{II}), \mathrm{Pd}(\mathrm{II})$ and $\mathrm{Pt}(\mathrm{II})$ complexes with Schiff base derived from N-methylhydrazinecarbothioamide and 2-hydroxy-5-methoxy-3-nitrobenzaldehyde. J Mol Struct. 2017;1130:791-8. https://doi.org/10.1016/j.molstruc.2016.10.099.

38. Taşpinar M, Denizler FN, Güven M, Yüksek V, Çetin S, and Dede S. The Cytotoxic Effect of 5-FU and Celastrol on Glioblastoma. Van Health Sciences J. 2019;11:6-10.

39. Gao A-M, Ke Z-P, Shi F, Sun G-C, Chen H. Chrysin enhances sensitivity of BEL-7402/ADM cells to doxorubicin by suppressing PI3K/Akt/Nrf2 and ERK/Nrf2 pathway. Chem Biol Interact. 2013;206(1):100-8. http://dx.doi.org/10.1016/J.cbi.2013.08.008.

40. Saczko J, Kamińska I, Kotulska M, Bar J, Choromańska A, Rembiałkowska N, et al. Combination of therapy with 5-fluorouracil and cisplatin with electroporation in human ovarian carcinoma model in vitro. Biomed Pharmacother. 2014;68(5):573-80. http://dx.doi.org/10.1016/j.biopha.2014.05.005.

41. Alkış ME, Buldurun K, Turan N, Alan Y, Yılmaz ÜK, Mantarcı A. Synthesis, characterization, antiproliferative of pyrimidine based ligand and its $\mathrm{Ni}(\mathrm{II})$ and $\mathrm{Pd}(\mathrm{II})$ complexes and effectiveness of electroporation. J Biomol Struct Dyn. 2020;1-11. https://doi.org/10.1080/07391102.2020.1852965.

42. Saleem K, Wani WA, Haque A, Lone MN, Hsieh M-F, Jairajpuri MA, et al. Synthesis, DNA binding, hemolysis assays and anticancer studies of copper(II), nickel(II) and iron(III) complexes of a pyrazoline-based ligand. Future Med Chem. 2013;5(2):13546. http://dx.doi.org/10.4155/FMC.12.201.

43. Sersa G, Krzic M, Sentjurc M, Ivanusa T, Beravs K, Kotnik V, et al. Reduced blood flow and oxygenation in SA-1 tumours after electrochemotherapy with cisplatin. Br J Cancer. 2002;87(9):1047-54. http://dx.doi.org/10.1038/sj.bjc.6600606.

44. Cemazar M, Parkins CS, Holder AL, Kranjc S, Chaplin DJ, Sersa G. Cytotoxicity of bioreductive drug tirapazamine is increased by application of electric pulses in SA-1 tumours in mice. Anticancer Res. 2001;21(2A):1151-6.

45. Cemazar M, Sersa G. Recent advances in electrochemotherapy. Bioelectricity. 2019;1(4):204-13. http://dx.doi.org/10.1089/BIOE.2019.0028.

\section{Figures}



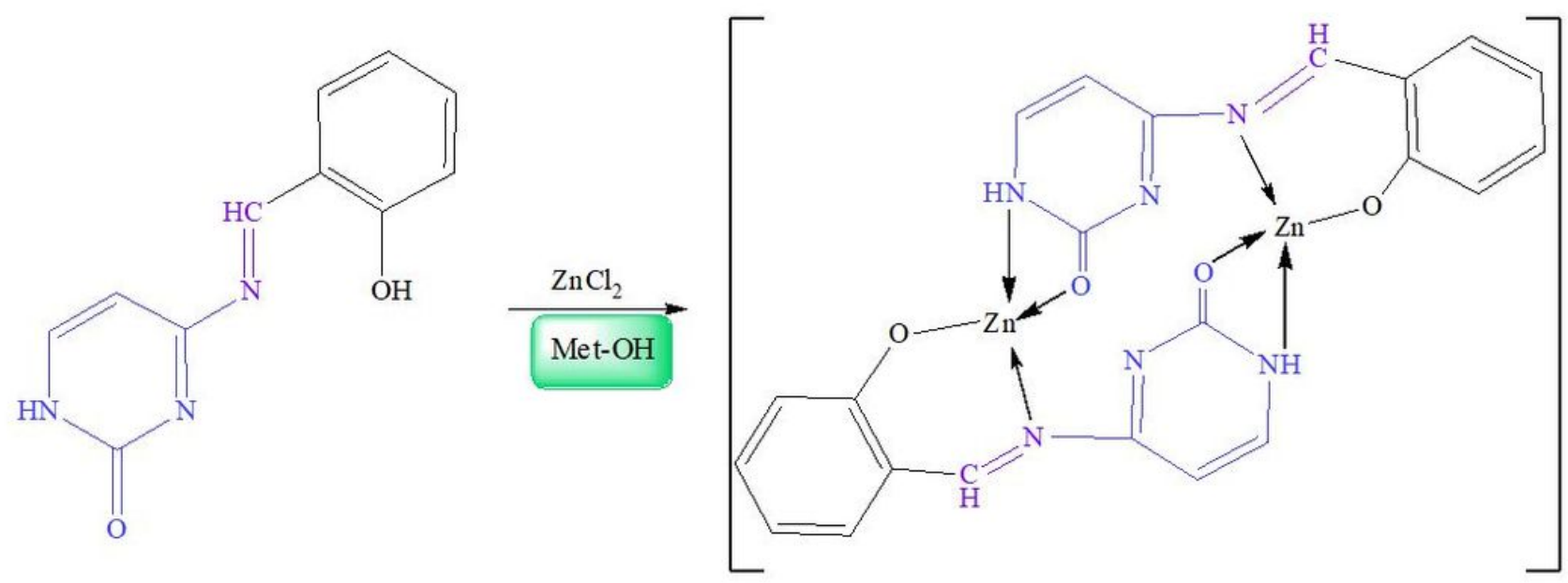

- $\mathrm{Cl}_{2} \mathrm{H}_{2} \mathrm{O}$

Figure 1

Preparation of Schiff base-Zn(II) complex

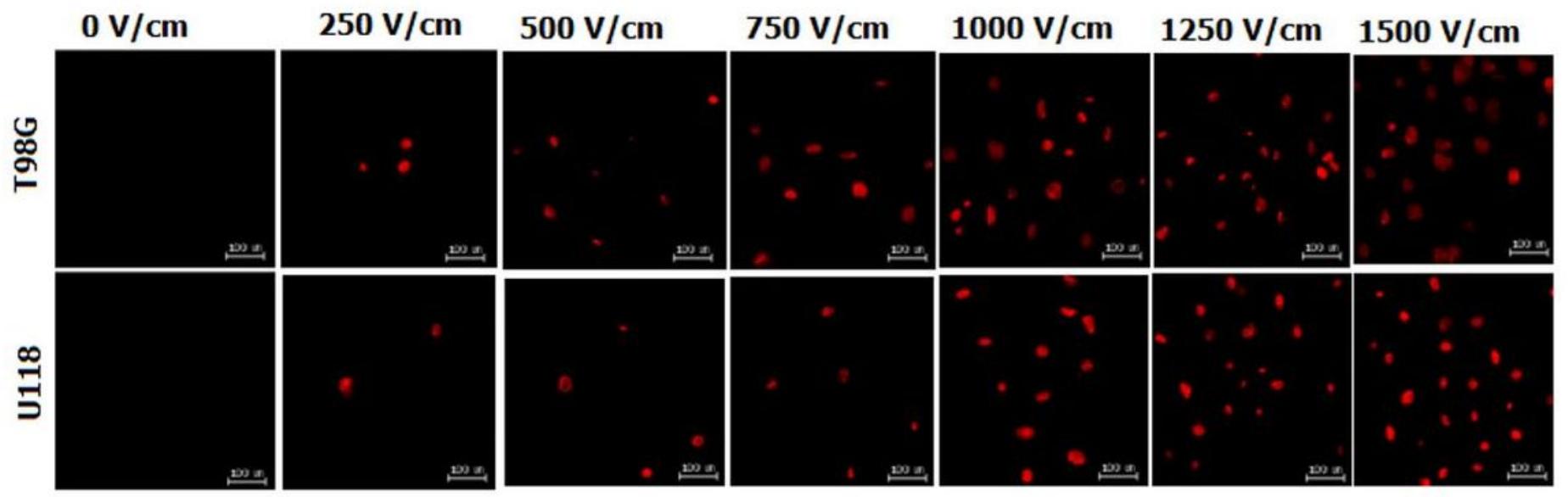

Figure 2

Fluorescence image of the cells obtained after the cells were subjected to the electric pulses of 0-1500 $\mathrm{V} / \mathrm{cm}$. The images were obtained by a fluorescence microscope at the magnification of $40 \mathrm{x}$. Scale bar $=$ $100 \mu \mathrm{m}$. 


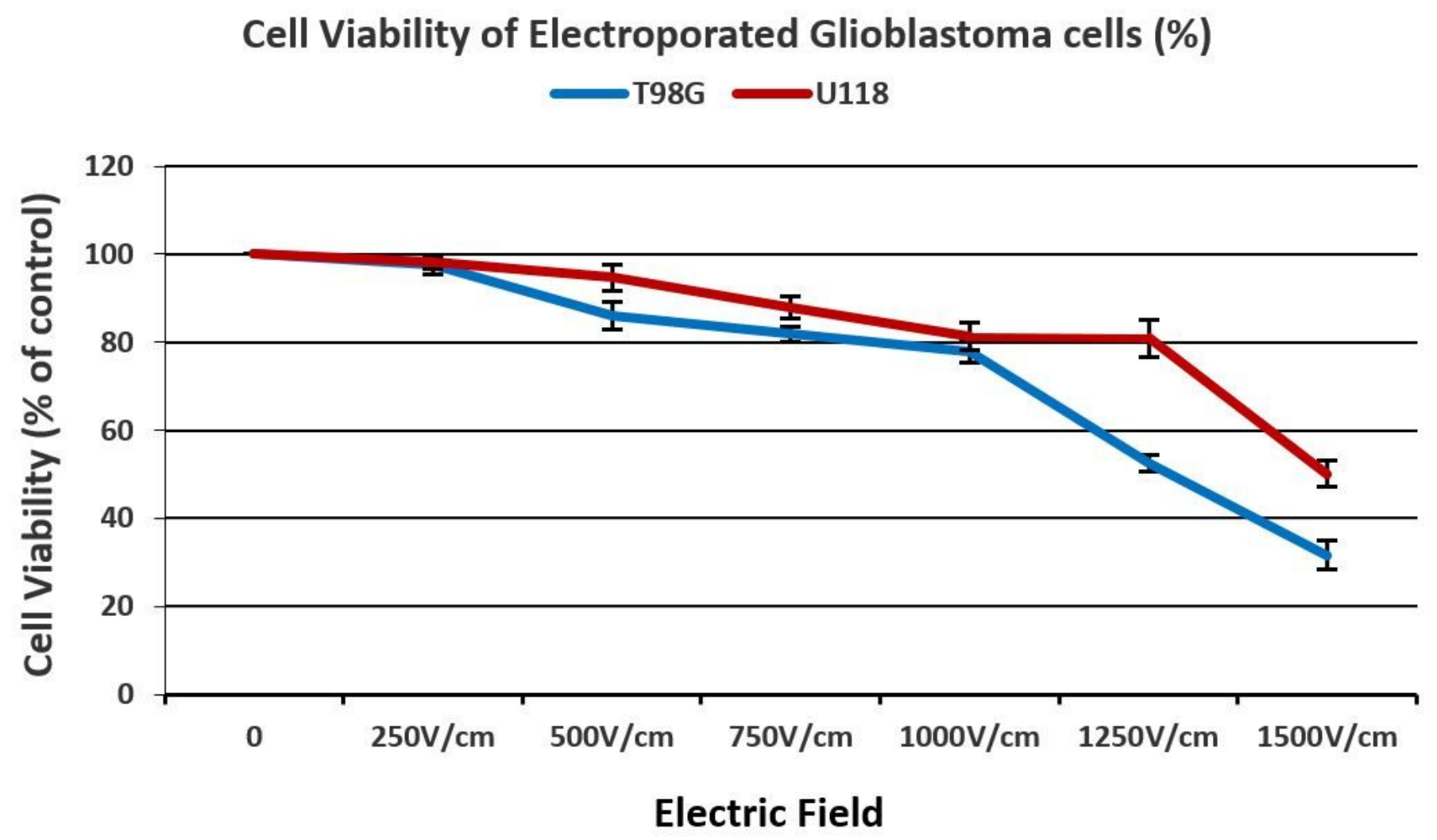

Figure 3

Cell viability of the T98G and U118 cells 24 hours after the electroporation. The data obtained from 4 independent experiments are expressed in mean \pm SD. 


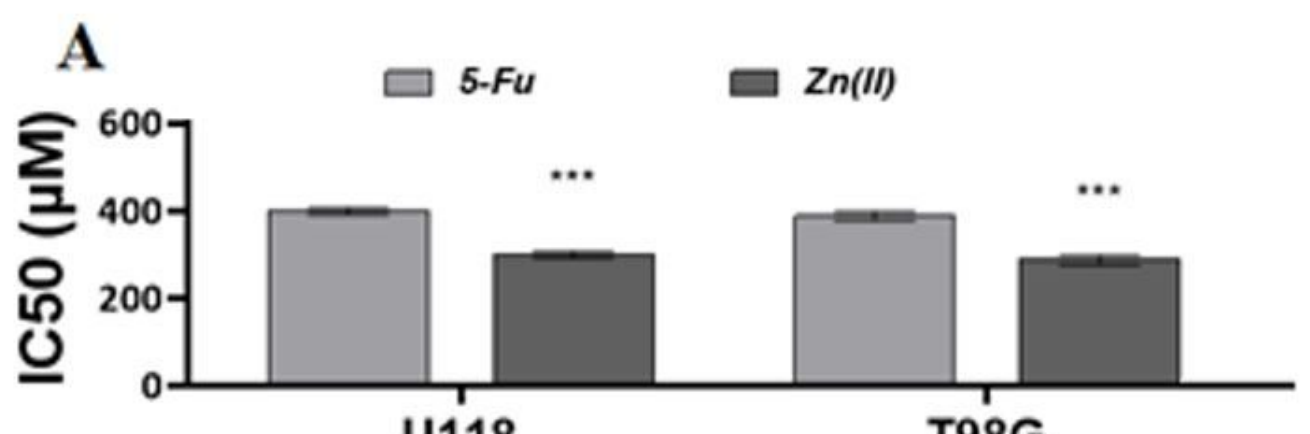

U118
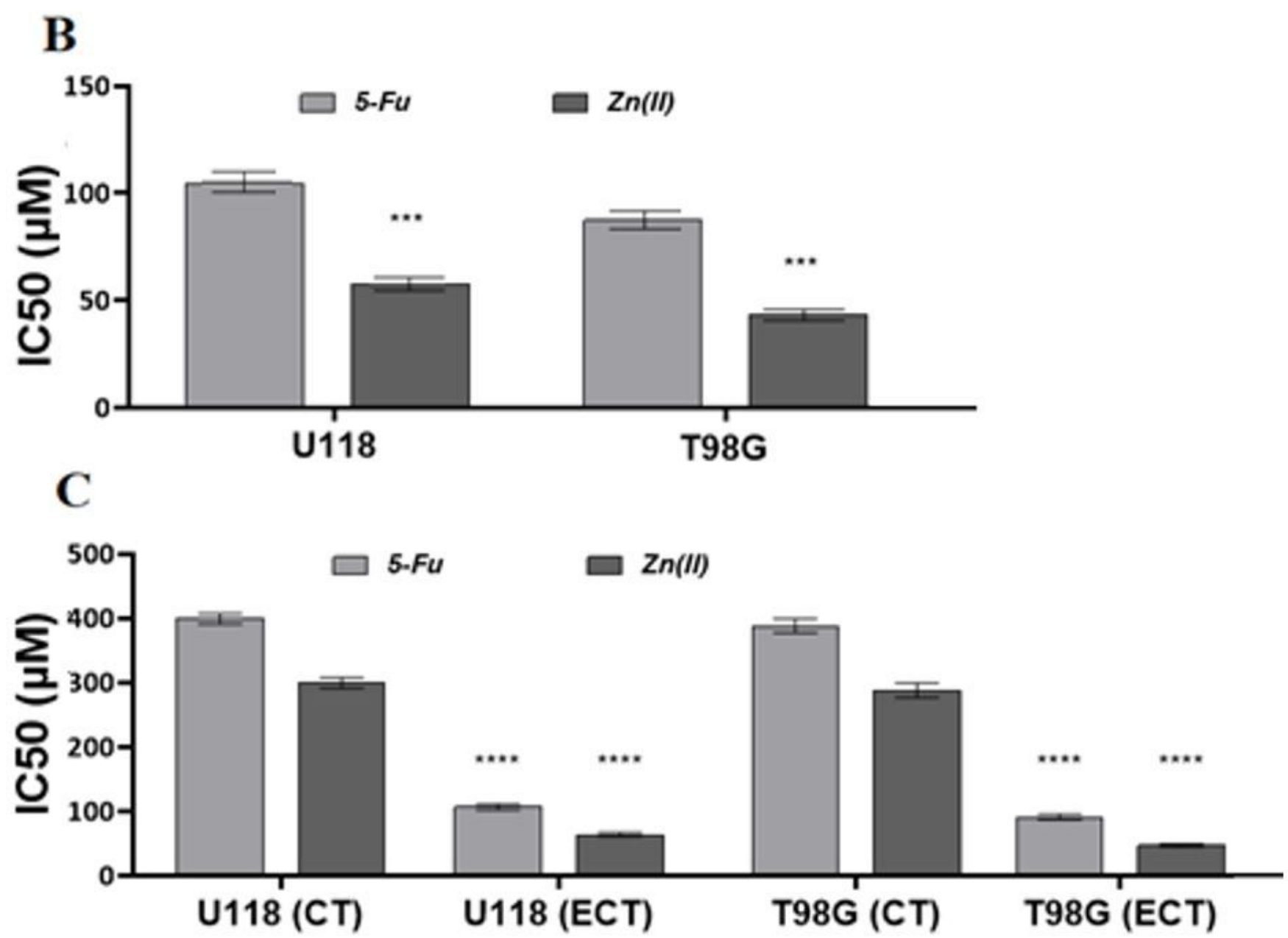

Figure 4

IC50 values of 5-FU and new Zn(II) complex against T98G and U118 glioblastoma cells, alone or in combination with EP (ECT), at 24 hours after treatment. (a) Comparison of the IC50 value of Zn(II) with 5FU in terms of statistical significance. (b) Comparison of the IC50 values of Zn(II)+EP with 5-FU+EP statistically. (c) 5-FU+EP, 5-FU and Zn(II)+EP, Zn(II) were compared among themselves. Statistically significant difference was observed between groups at different levels $\left(\star \star \star P<0.001,{ }^{\star}{ }^{*} * \star P<0.0001\right)$.

\section{Supplementary Files}


This is a list of supplementary files associated with this preprint. Click to download.

- GraphicalAbstract.docx 